\title{
ETV6 Gene Rearrangement
}

National Cancer Institute

\section{Source}

National Cancer Institute. ET V6 Gene Rearrangement. NCI Thesaurus. Code C155992.

A molecular abnormality indicating rearrangement of the ETV6 gene. 